\title{
Removal of BTEX from aqueous solutions by paper mill sludge-based activated carbon
}

\author{
Ehsan Aghdam , Behnoush Aminzadeh*, Majid Baghdadi, Mohammad Alizadeh Fard \\ ${ }^{1}$ Department of Environmental Engineering, Graduate Faculty of Environment, University of Tehran
}

Corresponding author: Behnoush Aminzadeh

E - mail: bamin@ut.ac.ir

Tel: +982161113163

, Fax: +98 2166407719

\begin{abstract}
The removal of BTEX (benzene, toluene, ethyl-benzene and p-xylene) from contaminated groundwater was evaluated by paper mill sludge-based activated carbon, prepared by chemical activation and pyrolysis. The effects of $\mathrm{pH}$, time, adsorbent dosage and adsorbate concentration were studied through batch adsorption experiments. Selected physical and chemical characteristics of the adsorbents, such as specific surface area $\left(613 \mathrm{~m}^{2} / \mathrm{g}\right)$, pore volume distribution (micropore: $277 \mathrm{~cm}^{3} / \mathrm{g}$, mesopore: $365 \mathrm{~cm}^{3} / \mathrm{g}$ ) and surface functional groups (carboxylic, alkyl and aliphatic groups) were determined by $\mathrm{N} 2$ adsorption-desorption diagram and FTIR, respectively. The removal efficiency of the four target compounds would be more than $92 \%$, which the initial concentrations of BTEX and the adsorbent dosage were $40 \mathrm{mg} / \mathrm{l}$ and $1000 \mathrm{mg} / \mathrm{l}$, respectively. It was proved that $\mathrm{pH}$ and ionic strength have insignificant effects on the adsorption efficiency. The order of adsorption amount in all experiments was > ethyl-benzene $>$ toluene $>$ benzene. The kinetic data proved a closer fit to the pseudo-first-order model. The isotherm experimental data showed a better fit to either Freundlich or Langmuir model. In addition, a series of experiments was conducted to evaluate the capacity of the adsorbent in adsorbing the BTEX from a groundwater sample contaminated with gasoline.
\end{abstract}

\section{Indexing terms/Keywords}

Removal; BTEX; Adsorption; Paper mill sludge-based activated carbon; Groundwater

\section{Academic Discipline And Sub-Disciplines}

Chemistry, Environmental Engineering

\section{SUBJECT CLASSIFICATION}

Environmental Chemistry Subject Classification

\section{TYPE (METHOD/APPROACH)}

Experimental study

\section{Council for Innovative Research}

Peer Review Research Publishing System

Journal: Journal of Advances in Chemistry

Vol. 11, No. 1

editorjaconline@gmail.com

www.cirjac.com 


\section{INTRODUCTION}

Nowadays, production and storage of gasoline are increasing, leading to the widespread release of mono aromatic hydrocarbons including benzene, toluene, ethyl-benzene and xylenes (BTEX) into soil and groundwater. After releasing into the environment, these compounds can eventually threat people's health. These compounds have been used extensively in several industries as solvents to produce rubbers, plastics, resins, nylon, lubricants, dyes, detergents, drugs, pesticides, paints, lacquers, and adhesives [1]. Gasoline leakage from underground storage tanks and transfer pipes are the main sources of soil and groundwater contamination with BTEX [2]. These compounds have been associated with long-term negative health effects. For example, Benzene is toxic to the hematopoietic system and can affect the central nervous system, leading to anemia and leukemia [3]. Since BTEX pose serious risk to people's heath, these compounds have been classified as priority pollutants in the World Health Organization's (WHO) drinking water standards. WHO puts strict limitations on these mono aromatic compounds. For instance, the allowable concentration of benzene in drinking water has been set $10 \mathrm{ppb}[3,4]$ In addition, the solubility of these compounds in water is noticeable, consequently BTEX are able to spread through groundwater.

Researchers have recommended different BTEX removal methods from aqueous solution. Air stripping is effective method for BTEX removal in aqueous solutions. Even though air stripping is a promising removal method, it does not destroy pollutants; it transfers them from aqueous phase to air. Application of advanced oxidation processes (AOPs) seems to be another effective way for treating contaminated groundwater, but the production of by-products is a problem that should be considered.

Adsorption is one of the old and efficient removal methods [5]. since the adsorbent can be recycled, and remove contaminants without producing by-products. In addition, easy combination with other methods such as biological ones, providing system stability, improving nitrification, higher hydraulic capacity for existing plants and removal of nonbiodegradable organics, enhancing quality of the sludge for better processing [6] and excellent porosity and surface chemistry [7] are some of several advantages of using adsorbents especially powdered activated carbon. Capability of novel adsorbents such as carbon nanotubes and their surface modified forms to remove BTEX from aqueous solutions were also investigated [8]; however, high production cost has been mentioned as the main drawback. Many natural materials and their modified forms such as diatomite [2] and montmorillonite [9] and zeolites [10] have been examined as BTEX adsorbents.

Preparing adsorbents from waste materials has attracted researchers' attention. This approach has an additional benefit for omitting huge costs of waste management and disposal. Some precursors of adsorbents are agricultural wastes [11] industrial waste[12], sewage sludge [13] and paper mill sludge [14].

According to researches, the more organic ingredients had the precursor, the more efficient would be the wastebased adsorbent. Paper mill sludge is one of the organic compounds-rich materials which should be disposal, because of containing hazardous materials [15]. However, activated carbon prepared from this sludge is capable to adsorb contaminants such as dyes [15], and heavy metals [16]. Because of its appropriate characteristics such as micropore structure and presence of various oxygenated functional groups, its capability to adsorb BTEX from aqueous solutions is expected.

In this study, chemical activation by $\mathrm{ZnCl}_{2}$ followed by pyrolysis in nitrogen atmosphere was performed to prepare adsorbent from paper mill sludge. Furthermore, some physical and chemical properties of the produced activated carbon were determined by applying BET model on N2 adsorption-desorption data, and FTIR. Then, the performance of produced adsorbent for BTEX adsorption from synthetic groundwater solutions was evaluated. The effects of $\mathrm{pH}$, contact time, adsorbent dosage, salt concentration (ionic strength), and initial concentration of BTEX on the adsorption were examined. The adsorption capacity of the adsorbent for BTEX was investigated by determining the equilibrium isotherms.

\section{EXPERIMENTAL}

\subsection{Instruments}

The remaining BTEX concentration after adsorption was measured by gas chromatography-mass spectrometry (GC/MS). The sampled was prepared for GC by purge and trap method. The carrier gas was Nitrogen (40 ml/min) which was bubbled for $10 \mathrm{~min}$. The volatile compounds were adsorbed to the column (Tenax/Charcoal, $30 \mathrm{~cm}$ ). For desorbing the compounds into a gas chromatographic column, the sorbent column was heated to $225{ }^{\circ} \mathrm{C}$ and backflushed with helium [17]. Then, the column was warmed up to $35{ }^{\circ} \mathrm{C}$, then $100{ }^{\circ} \mathrm{C}$ and then $265^{\circ} \mathrm{C}$. Detention time in each of three temperatures were 2 min [18]. The detection limit of the GC/MS was $1 \mathrm{ppb}$.

\subsection{Raw Materials and Preparations}

The paper mill sludge was obtained from the first sedimentation basin of paper mill wastewater treatment plant (Chooka Wood and Paper Industries, Gilan, Iran). All experiments were conducted in groundwater solutions with the properties presented in Table1. The $\mathrm{ZnCl}_{2}$ and BTEX was purchased from Merck. Co, Germany. Conventional gasoline was taken from Tehran oil Refinery in Tehran, and was used to conduct experiments in real-like conditions. 
Table1. Characteristics of groundwater used for BTEX adsorption experiments

\begin{tabular}{|c|c|c|c|c|c|c|c|c|c|}
\hline $\mathrm{Mg}^{2+}$ & $\mathrm{Ca}^{2+}$ & $\mathrm{pH}$ & TDS & temperature & $\mathrm{PO}_{4}^{{ }^{3-}}$ & Alkalinity & $\begin{array}{c}\text { Total } \\
\text { hardness }\end{array}$ & $\mathrm{SO}_{4}{ }^{2-}$ & $\mathrm{NO}_{3}{ }^{2-}$ \\
\hline $\begin{array}{c}14 \mathrm{mg} / \mathrm{l} \\
\mathrm{as} \\
\mathrm{CaCO}_{3}\end{array}$ & $\begin{array}{c}310 \mathrm{mg} / \mathrm{l} \\
\mathrm{as} \\
\mathrm{CaCO}_{3}\end{array}$ & $6.8-7$ & $\begin{array}{c}399 \\
\mathrm{mg} / \mathrm{l}\end{array}$ & $28^{\circ} \mathrm{C}$ & $\begin{array}{l}0.03 \\
\mathrm{mg} / \mathrm{l}\end{array}$ & $\begin{array}{l}276 \mathrm{mg} / \mathrm{l} \\
\mathrm{as} \\
\mathrm{CaCO}_{3}\end{array}$ & $\begin{array}{c}324 \mathrm{mg} / \mathrm{l} \\
\mathrm{as} \\
\mathrm{CaCO}_{3}\end{array}$ & $\begin{array}{c}116 \\
\mathrm{mg} / \mathrm{l}\end{array}$ & $57 \mathrm{mg} / \mathrm{l}$ \\
\hline
\end{tabular}

\subsection{Preparation of Adsorbent}

In order to prepare the adsorbent, a method similar to one introduced by Khalili [19] was applied. The raw sludge was dried at $105^{\circ} \mathrm{C}$ for $24 \mathrm{~h}$ to achieve constant weight. Then, it was comminuted and sieved into a uniform size of 30 mesh to provide material with uniform size and optimum surface area for better interact with the activating agent, ZnCl2. Subsequently, $20 \mathrm{~g}$ of dried, crushed and sieved sludge were added to $100 \mathrm{ml}$ water containing $20 \mathrm{~g} \mathrm{ZnCl} 2$. The slurry was mixed with a magnetic stirrer for $8 \mathrm{~h}$ at room temperature $\left(25^{\circ} \mathrm{C}\right)$. Upon drying, the activated/dried sludge was crushed again into fine powders. The pyrolysis was carried out under a flow of nitrogen gas $(70 \mathrm{ml} / \mathrm{min})$ at $800{ }^{\circ} \mathrm{C}$ for $2 \mathrm{~h}$. The temperature was raised at a rate of approximately $20^{\circ} \mathrm{C} / \mathrm{min}$. Upon completion of the pyrolysis, sample was removed from the reactor and crushed by mortar and pestle. After pyrolysis, the carbonized material was washed with $500 \mathrm{ml}$ of $1.2 \mathrm{M}$ $\mathrm{HCl}$ and then with $500 \mathrm{ml}$ of distilled water to extract residual organic and mineral materials. The produced activated carbon was then placed in oven for $8 \mathrm{~h}\left(110^{\circ} \mathrm{C}\right)$.

\subsection{Adsorbent characterization}

The specific surface area, pore size distribution and total pore volume were obtained by N2 adsorption-desorption isotherms at 77K. The SBET values were calculated by the BET method and the pore size distribution was determined by the Dubinin-Radushkevich equation. The average pore diameter was obtained by BJH method. The surface physical morphology of the adsorbent was observed by a Scanning Electron Microscope (SEM). The surface functional groups were investigated by FTIR [19].

\subsection{Adsorbate solutions}

The chemicals tested in this study were benzene, toluene, ethylbenzene, and $p$-xylene. All chemicals used in this research were purchased from Merck Co, Germany. BTEX stock solution (1000 mg/L, each component), was prepared by adding the appropriate amounts of each mono aromatics in $50 \mathrm{ml}$ volumetric flask containing methanol and volume was made up to mark with the same The standard solution of BTEX was prepared by spiking $1 \mathrm{ml}$ of each stock solution into a $100 \mathrm{ml}$ flask filled with groundwater to achieve a $10 \mathrm{mg} / \mathrm{L}$ solution of each compound. This concentration was chosen because BTEX concentrations in polluted groundwater range from low $\mu \mathrm{g} / \mathrm{l}$ in old contaminated groundwater to $>10 \mathrm{mg} / \mathrm{l}$ in new ones. Synthetic gasoline solutions were prepared through dissolving $2 \mathrm{~g}$ of gasoline in $200 \mathrm{ml}$ methanol. For experiments, diluted solutions of this stock solution were used.

\subsection{Kinetic batch experiments}

The batch adsorption experiments were carried out to determine the effect of parameters such as $\mathrm{pH}(3,5,7,9,11)$, contact time $(0.5,1,1.5,2,2.5 \mathrm{hr})$, adsorbate concentration $(10,20,30,40 \mathrm{mg} / \mathrm{l})$, and salt effect $(124,300,700 \mathrm{mg} / \mathrm{l}$ of calcium chloride) on the removal of BTEX from groundwater solutions by activated carbon prepared from paper mill sludge. All the adsorption experiments were conducted at room temperature $\left(25^{\circ} \mathrm{C}\right)$ and the solutions were stirred by a magnetic stirrer. After mixing period, the suspensions were maintained $15 \mathrm{~min}$ to settle, and clear supernatant was analyzed for organic pollutants by GC/MS. The experiments were duplicated and average values were reported. Blank samples (BTEX solution without the adsorbent) were also used to determine the value of BTEX volatilization and adsorption on the surface of the container and magnet. The blank recoveries ranged from 90 to $95 \%$ and the data were not adjusted for these recoveries. 


\section{RESULTS AND DISCUSSION}

\subsection{Adsorbent Characterization}

\subsubsection{Porous Characterization of the Adsorbents}

The most common method to analyze porous structure of an adsorbent is employing N2 adsorption-desorption isotherm data in $77 \mathrm{~K}$ which is shown in Fig. 1. ]

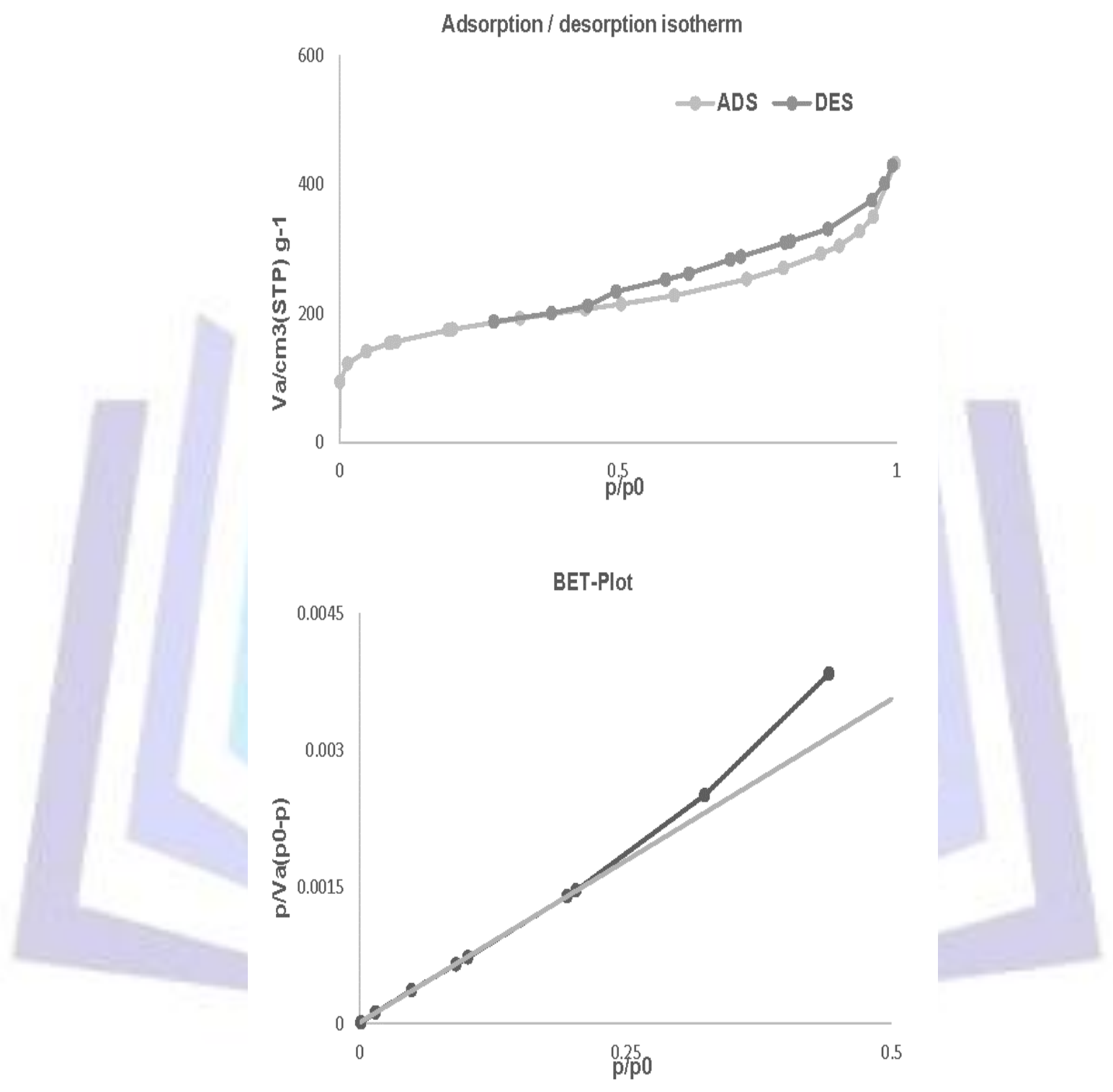

Fig1. $\mathrm{N}_{2}$ adsorption-desorption plot and BET-plot

In order to obtain special surface area, the BET equation was applied to this data in the relative pressure range of $\left(\mathrm{p} / \mathrm{p}_{0}\right): 0.05-0.3$. The basic assumption of BET was formation of a monolayer of adsorbate on the whole adsorbent surface. The surface area was calculated by knowing the dimensions of the adsorbate (here $\mathrm{N}_{2}$ ) and amount of adsorbed $\mathrm{N}_{2}$ [19]. Fig. 2 is BJH plot of the adsorbent. This plot was gained from $\mathrm{N}_{2}$ adsorption-desorption data too. By applying "Dubinin and Radushkevich" equation () to $\mathrm{N}_{2}$ adsorption-desorption data in $\mathrm{p} / \mathrm{p} 0<0.1$ (in which the plot is linear), micropore structure of the adsorbent can be analyzed. 


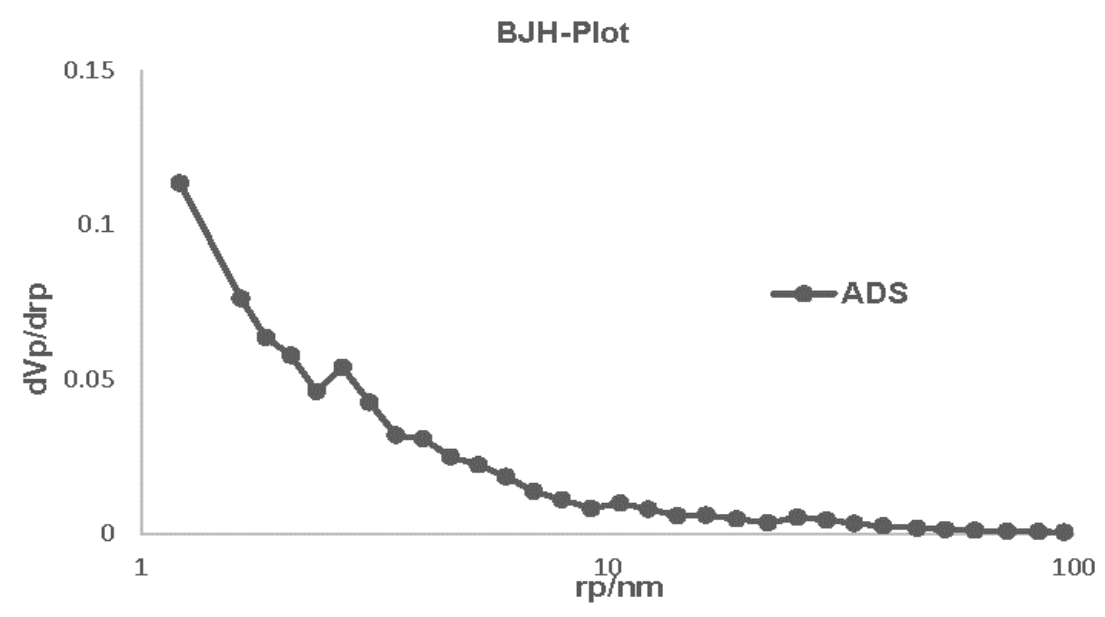

Fig 2. BJH plot of $\mathrm{N}_{2}$ adsorption-desorption data of the adsorbent

The intercept of the linear part of plot to $y$-axis is micropore volume. Deviation from linear form is indicative of multilayer formation and capillary condensation in mesopore volume (Fig. 3) [19].

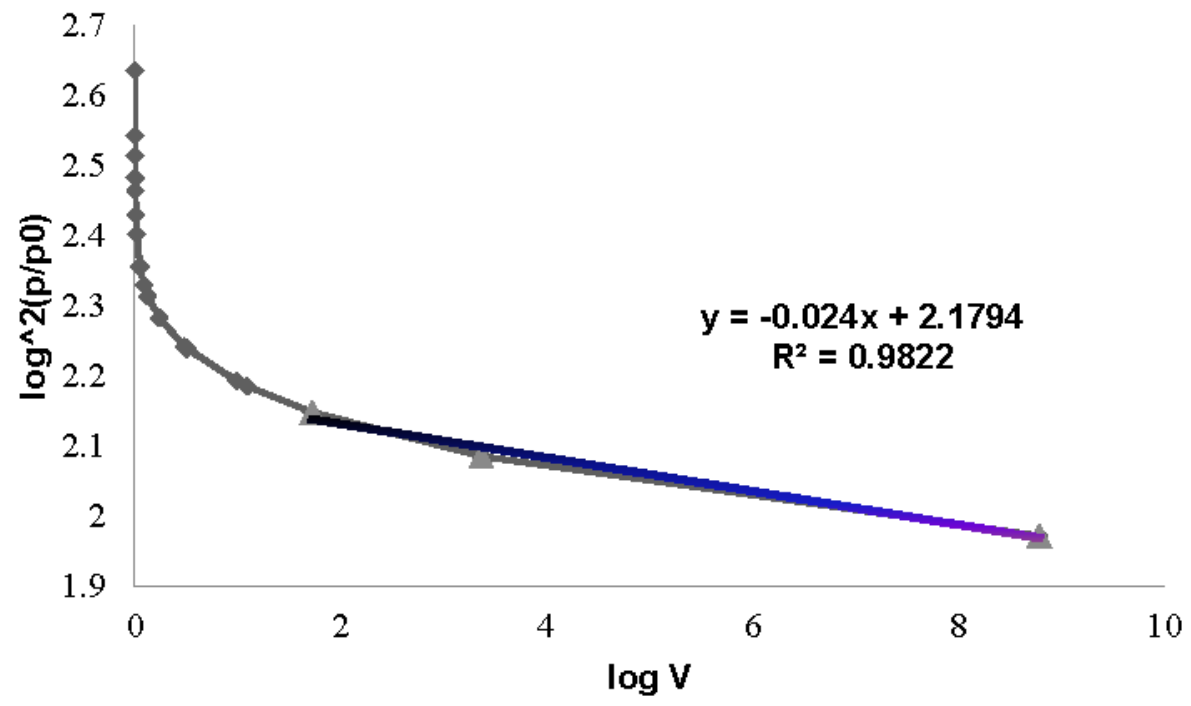

Fig 3. Applying D-R equation to $\mathrm{N}_{2}$ adsorption-desorption data

$\log W=\log W 0-B(T / \beta) 2 \log 2\left(p_{0} / p\right) \quad$ Equation 1

W : Volume adsorbed, W0: Micropore volume, B: Structural constant, $\beta$ : Similarity coefficient, T: Temperature, $p_{0} / p$ : Inverse of the partial pressure

Table 2 summarizes the porosity results of the adsorbent as derived by the BET and D-R method. As seen, its surface area is over $613 \mathrm{~m}^{2} / \mathrm{g}$, and pore volume is over $0.64 \mathrm{~m}^{3} / \mathrm{g}$. Fig. 4 shows the SEM images of the prepared adsorbent in two scales. 

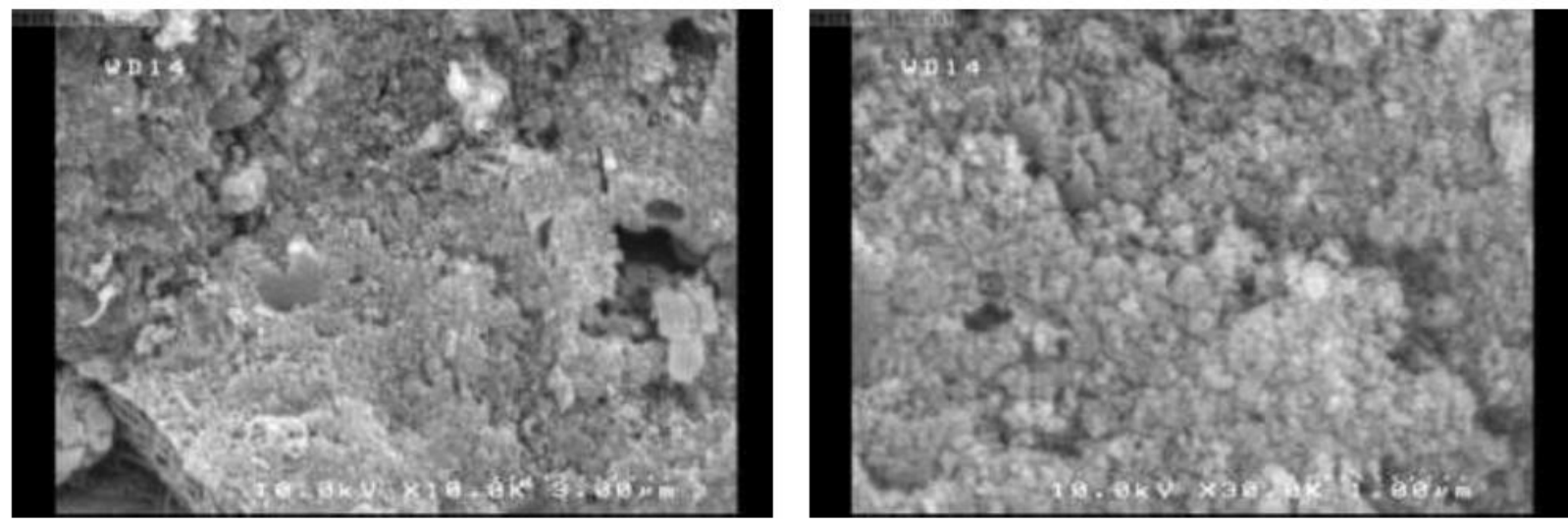

Fig 4. SEM images of the adsorbent

As shown in Fig. 4, there are pores with a large variety of sizes and shapes, which was the result of organic compounds' (especially lignine) decomposition during pyrolysis, and removal of remaining matters after acid washing. This variety indicates heterogeneity of its surface and contributes to its ability of adsorbing organic pollutants.

Table 2. Porosity characteristics of the adsorbent

\begin{tabular}{|c|c|}
\hline \multicolumn{1}{|c|}{ SBET $_{\text {BET }}$} & $613.38 \mathrm{~m}^{2} \mathrm{~g}^{-1}$ \\
\hline Total pore volume $(=0.990)$ & $0.6422 \mathrm{~cm}^{3} \mathrm{~g}^{-1}$ \\
\hline Average pore diameter & $4.188 \mathrm{~nm}$ \\
\hline Micropore volume & $0.277 \mathrm{~cm}^{3} \mathrm{~g}^{-1}$ \\
\hline Mesopore volume & $0.365 \mathrm{~cm}^{3} \mathrm{~g}^{-1}$ \\
\hline
\end{tabular}

\subsubsection{FTIR analysis}

In order to gain better insight on the surface functional groups available on the carbons surface, FTIR spectra for the tested adsorbents are recorded as shown in Fig. 5.

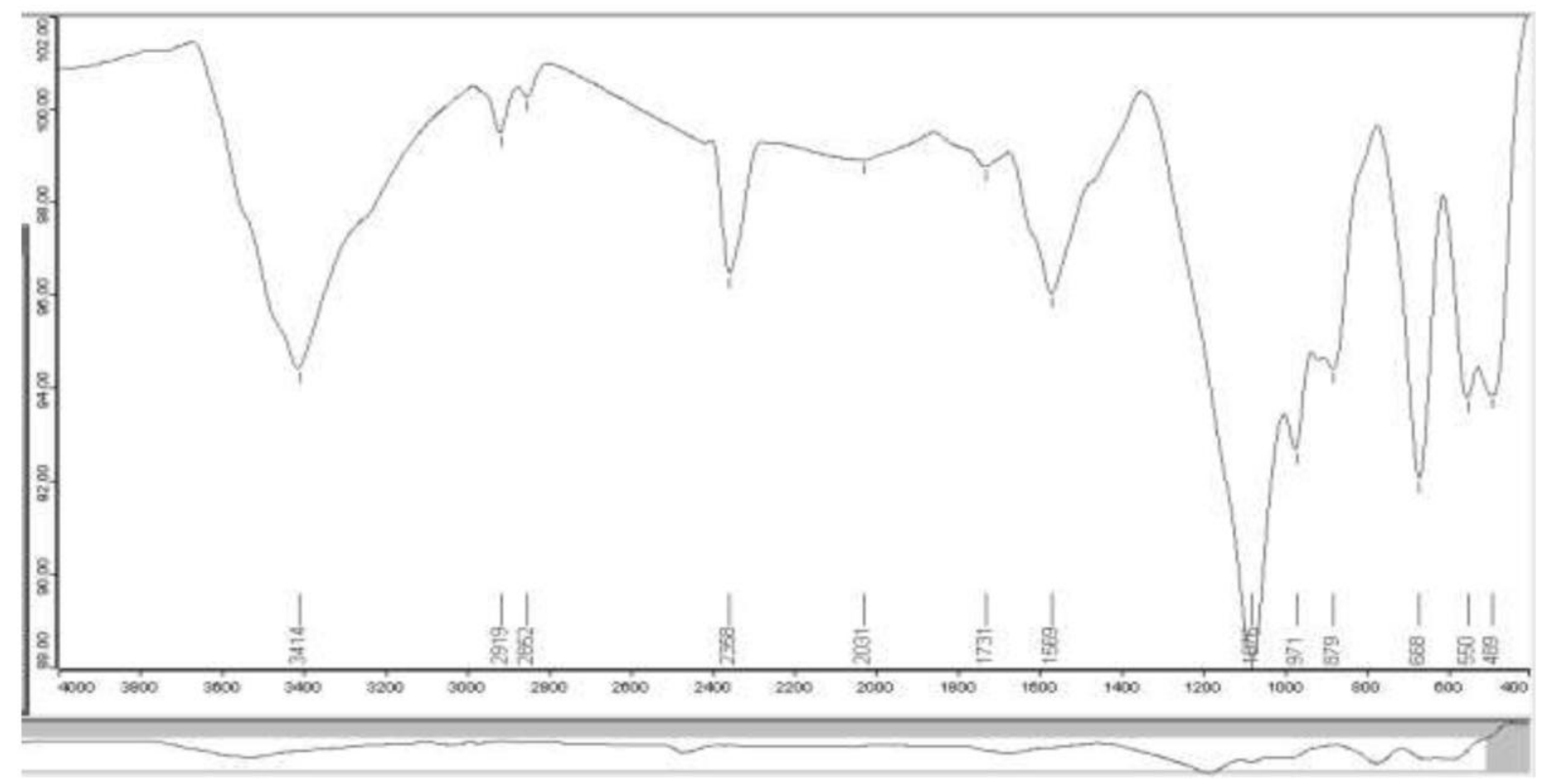

Fig 5. FTIR Analysis of the adsorbent 
The spectra display some significant apparent bands. The band at about $3414 \mathrm{~cm}^{-1}$ was assigned to $-\mathrm{OH}$ stretch from carboxylic groups $(-\mathrm{COOH})$ [20]. Bands at 2919 and $2850 \mathrm{~cm}-1$ correspond to alkyl groups. These bands are also characteristics of $\mathrm{C}-\mathrm{H}$ stretching of aliphatic moieties, most likely associated to the glicydic part of lipids [21]. The band at $1731 \mathrm{~cm}^{-1}$ is typical of $\mathrm{C}=\mathrm{O}$ bond and is probably due to the oxidation of cellulose fibers or the presence of organic compounds with oxygenated groups. The band at $1569 \mathrm{~cm}^{-1}$ is characteristic of the protein structures [21]. It may be due to $-\mathrm{NH}$ bending too [22]. The band at about $1056 \mathrm{~cm}^{-1}$ was associated to $\mathrm{C}-\mathrm{O}$ stretching of alcoholic compounds which evidenced that the carboxylic groups $(-\mathrm{COOH})$ exist in the sludge-based activated carbon (SAC) [20]. These functional groups exist in the external and internal surface of SAC, which increase the surface polarity and further alter the surface charges properties [20]. These bands and their associated functional groups contribute to the adsorbent's chemical surface heterogeneity. This combined with physical heterogeneity, as described above, enhances adsorption efficiency.

\subsection{Comparative studies}

There are a few papers investigating characterization and adsorption capability of adsorbents prepared from paper mill sludge. Table 3. shows comparison between characteristics of prepared adsorbent in this study and other studies. The precursor of all adsorbents is paper mill sludge. The preparation method used in this study and [19] are similar, however, there are some differences in characteristics of adsorbents. in Khalili's work, more micropores in adsorbent structure $(71 \%)$ leads to more specific surface area $\left(1015 \mathrm{~m}^{2} / \mathrm{g}\right)$ despite its slightly less total pore volume $\left(0.534 \mathrm{~m}^{3} / \mathrm{g}\right)$ than total pore volume of the adsorbent in the current study $\left(0.642 \mathrm{~m}^{3} / \mathrm{g}\right)$. This difference can be attributed to additional processes such as adjustment of chemical activation temperature $\left(80^{\circ} \mathrm{C}\right)$, physical activation after washing with acid and water, and exposure to light and humidity after chemical activation in Khalili's work. Less surface area $\left(280 \mathrm{~m}^{2} / \mathrm{g}\right)$ and volume $(0.038$ $\mathrm{m}^{3} / \mathrm{g}$ ) of the adsorbent prepared by [15] than other ones, proves remarkable effect of chemical activation in pore structure development. In all of these studies, different kinds of adsorbents were made and their adsorption capability was investigated. On the other hand, chemical activation by $\mathrm{ZnCl} 2$ contributes to pore structure more than activation by $\mathrm{KOH}$. Finally, although sources of paper mill sludge are different, great difference of surface area between processed sludge samples and unprocessed ones [14,23] is indicative of chemical and physical activation effect on porosity of the adsorbent.

Table 3. Comparison of some adsorbents prepares from paper mill sludge, S: specific surface area, V: volume, D: mean pore diameter

\begin{tabular}{|c|c|c|c|c|c|c|}
\hline $\mathrm{S}\left(\mathrm{m}^{2} / \mathrm{g}\right)$ & $\begin{array}{c}V \\
\left(\mathrm{~m}^{3} / \mathrm{g}\right)\end{array}$ & $D\left(A^{0}\right)$ & Micropore & Method of preparation & Adsorbate & Reference \\
\hline 613 & 0.642 & 83.76 & $\% 43$ & Chemical activation, pyrolysis & BTEX & This study \\
\hline 280 & 0.038 & 23.56 & - & $\begin{array}{c}\text { Carbonization and activation by } \\
\text { steam }\end{array}$ & dyes & Li, 2011 \\
\hline 1015 & 0.534 & 42.12 & $\% 71$ & Chemical activation, pyrolysis & $\mathrm{NO}_{\mathrm{x}}$ & Khalili, 2000 \\
\hline 245 & - & & - & $\begin{array}{c}\text { Carbonization, chemical activation by } \\
\mathrm{KOH} \text {, Physical activation }\end{array}$ & $\mathrm{Cu}, \mathrm{Cd}, \mathrm{Cr}$ & Kang,2006 \\
\hline 274.7 & 0.149 & 0.22 & $\% 41$ & Pyrolysis & $\mathrm{Cu}(\mathrm{II})$ & Mendez, 2009 \\
\hline 70 & - & & & Physical activation & $\begin{array}{c}\text { Phosphate, } \\
\text { methylene Blue }\end{array}$ & Hojamberdiev, 2008 \\
\hline 20 & - & - & - & Without processing & phenols & Calace, 2002 \\
\hline 12 & - & - & - & Without processing & $\mathrm{Pb}, \mathrm{Cu}, \mathrm{Ag}, \mathrm{Cd}$ & Calace, 2003 \\
\hline
\end{tabular}




\subsection{Adsorption Performance}

\subsubsection{Effect of $\mathrm{pH}$}

Fig. 6 shows the effects of $\mathrm{pH}$ on BTEX adsorption at $40 \mathrm{mg} / \mathrm{l}$ of BTEX, and $1000 \mathrm{mg} / \mathrm{l}$ of the adsorbent.

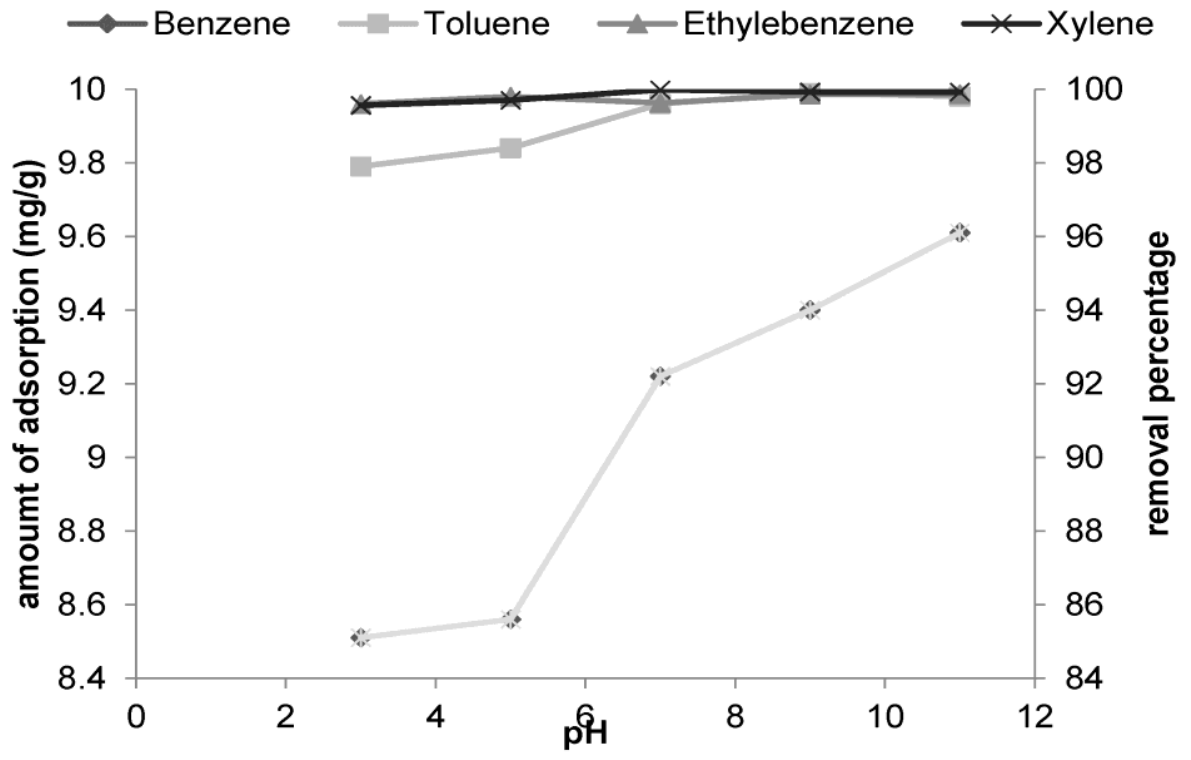

Fig 6. Effect of $\mathrm{pH}$ on adsorption percentage and capacity $(\mathrm{mg} / \mathrm{g})$

It was observed that the changes had insignificant effects on BTEX adsorption, reflecting high stability of the adsorbent in a wide $\mathrm{pH}$ range. Adsorption efficiency of toluene, ethylbenzene and xylene were above $98 \%$ in all $\mathrm{pHs}$ after $2 \mathrm{~h}$. The amount of adsorbed BTEX (each of them) on mass unit of adsorbent in all cases were between 8-10 mg/g The most noticeable effect of $\mathrm{pH}$ was on the adsorbtion of benzene. It ranged from $85.1 \%$ in $\mathrm{pH} 3$ to $96.1 \%$ in $\mathrm{pH} 11$. The increase of benzene removal by increase of $\mathrm{pH}$ can be attributed to the charge behavior of BTEX and surface charge of the adsorbent. BTEX compounds have somehow positively charged in the $\mathrm{pH}$ range of 3-11, however very small. As stated above, there are many functional groups on surface of the adsorbent. By increasing $\mathrm{pH}$, these functional groups dissociate more, and surface charge of the adsorbent gets more negative. Thus, it can absorb positively charged compounds better than in low pHs. However, this effect is negligible for toluene, ethylbenzene and xylene, since hydrophobic interactions have more important role than electrostatic interactions. This effect is more considerable in the case of adsorption of ionic compounds [8].

\subsubsection{Effect of Contact Time and Adsorption Kinetics}

Fig. 7 shows the effects of contact time on BTEX adsorption on the adsorbent, which initial concentrations of BTEX and adsorbent were $40 \mathrm{mg} / \mathrm{l}$ and $1000 \mathrm{mg} / \mathrm{l}$, respectively.

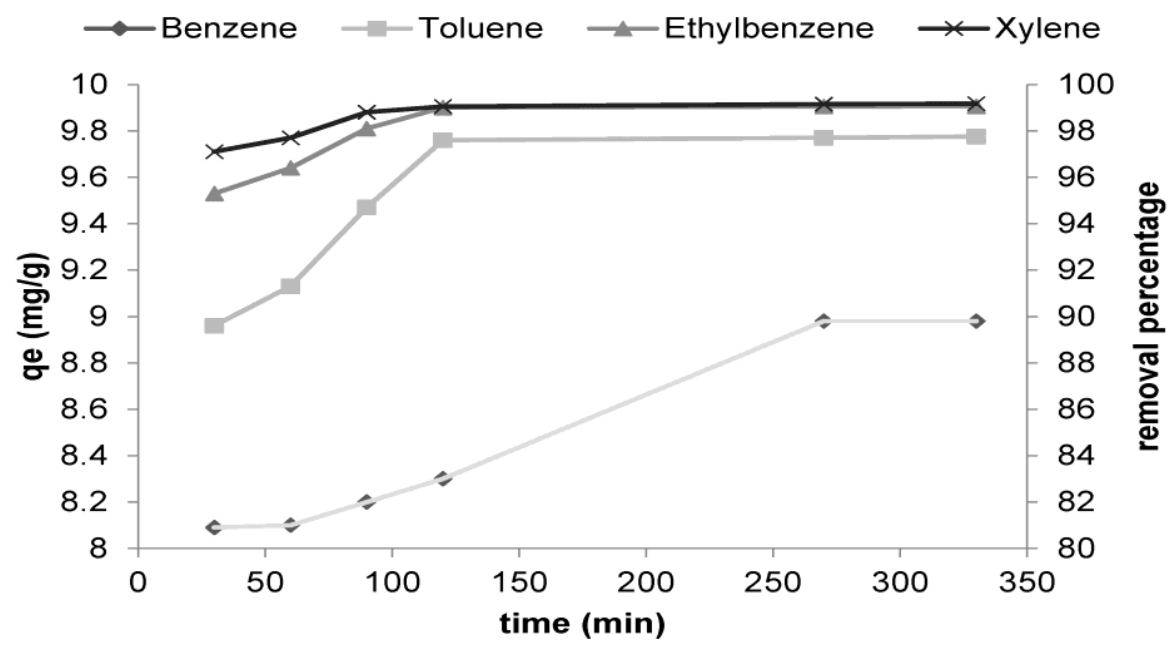

Fig 7. Effect of time on BTEX adsorption 
Abundant accessible pores, and a variety of functional groups, expedite the process of adsorption in first hour [9] and more than $90 \%$ adsorption of toluene, ethylbenzene and xylene was achieved. The adsorption of Benzene on the prepared adsorbent take a longer time to reach equilibrium. Equilibrium was reached for benzene after $270 \mathrm{~min}$ and for others after $120 \mathrm{~min}$ This is probably due to less hydrophobity of benzene than other compounds, leading to more availability of adsorption sites for other three compounds at first. The removal efficiency of benzene, toluene, ethylbenzene and $\mathrm{p}$ - xylene were in the order of $\mathrm{B}<\mathrm{T}<\mathrm{E}<\mathrm{X}$. It may be due to their molecular weight, boiling point, water solubility, and their hydrophobicity as below:

Molecular weight $(\mathrm{g} / \mathrm{mol})$ : $\mathrm{B}(78)>\mathrm{T}(92)>\mathrm{E}, \mathrm{X}(106)$; Boiling point $\left({ }^{\circ} \mathrm{C}\right)$ : $\mathrm{B}(80.1)>\mathrm{T}(110.7)>\mathrm{E}(136.2)>\mathrm{X}(138)$; Water solubility (mg/l): $B(1790)>T(530)>E(152)>X(150.5)$; Hydrophobicity (based on log Kow ): B (2.13)< $\mathrm{T}(2.69)<\mathrm{E}(3.15)<\mathrm{X}(3.15)$

\subsection{Adsorption kinetic models}

Adsorption kinetic models can elucidate the mechanism of adsorption and the efficiency of the adsorbents for the removal of pollutants. In order to get a better insight of adsorption mechanism, three different kinetic models including pseudo-first-order, pseudo-second-order, and intraparticle diffusion models were examined[9]. Pseudo-first order model can be shown as Equation 2

\begin{tabular}{|l|l|}
\hline $\operatorname{Ln}(q e-q t)=\operatorname{lnqe}-k 1 t$ & Equation 2 \\
\hline
\end{tabular}

In which, $\mathrm{qe}(\mathrm{mg} / \mathrm{g})$ and $\mathrm{qt}(\mathrm{mg} / \mathrm{g})$ are the the amount of adsorbate on unit mass of the adsorbent after equilibrium and at the given time $(\mathrm{t})$ respectively. By plotting $\ln (\mathrm{qe}-\mathrm{qt}$ ) versus $\mathrm{t}, \mathrm{k} 1$, the constant of pseudo-first order modelis obtained.

Pseudo-second order model can be shown as Equation 3

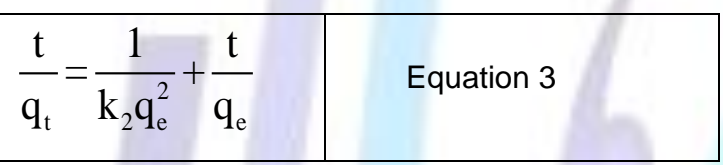

Plotting $t / q$ t versus $t$ gives $1 / q e$ as slope and $1 / k_{2} q e^{2}$ as intercept. The calculated qe can be compared by experimental qe.

The intraparticle diffusion kinetic is described by Equation 4.

\section{$\mathrm{q}_{\mathrm{t}}=\mathrm{k}_{\mathrm{id}} \mathrm{t}^{1 / 2}+\mathrm{C} \quad$ Equation 4}

In this equation, $\mathrm{kid}(\mathrm{g} / \mathrm{mg} \cdot \mathrm{min})$ is the rate constant of the intraparticle diffusion kinetic model. Linear plot of against has slope of value kid, and intercept of $\mathrm{C}$.

Table 4. shows kinetic constants of these models. The pseudo-second order model is fitted to the experimental data better than the pseudo-first order model and intraparticle diffusion model, because of the former one's correlation factor $\left(R^{2}\right)$ is approximately equal to one in all cases.

Table 4. Parameters of three different kinetic models

\begin{tabular}{|c|c|c|c|c|c|c|c|c|}
\hline \multirow{2}{*}{$\begin{array}{c}\text { Parameter } \\
\text { Contaminant }\end{array}$} & \multicolumn{4}{|c|}{ Pseudo-second order } & \multicolumn{2}{|c|}{$\begin{array}{l}\text { Pseudo-first } \\
\text { order }\end{array}$} & \multicolumn{2}{|c|}{$\begin{array}{c}\text { Intraparticle } \\
\text { diffusion }\end{array}$} \\
\hline & $\mathrm{q}_{\mathrm{e}, \text { experimental }} \mathrm{mg} / \mathrm{g}$ & $\mathrm{q}_{\mathrm{e}, \text { calculated }} \mathrm{mg} / \mathrm{g}$ & $\begin{array}{c}\mathrm{k}_{2} \\
\text { (g/mg.min) }\end{array}$ & $r^{2}$ & $\begin{array}{c}\mathrm{k}_{1} \\
(1 / \mathrm{min})\end{array}$ & $r^{2}$ & $\begin{array}{l}\mathrm{k}_{\mathrm{id}}(\mathrm{g} / \\
\mathrm{mg} \min )\end{array}$ & $r^{2}$ \\
\hline Benzene & 8.98 & 9.2 & 0.127187 & $\begin{array}{c}0.999 \\
3\end{array}$ & 0.0222 & 0.94 & 0.1049 & $\begin{array}{c}0.977 \\
4\end{array}$ \\
\hline Toluene & 9.775 & 10.08 & 0.020227 & $\begin{array}{c}0.998 \\
9\end{array}$ & 0.0493 & 0.93 & 0.1477 & $\begin{array}{c}0.953 \\
7\end{array}$ \\
\hline Ethylbenzene & 9.906 & 10.04 & 0.04975 & $\begin{array}{c}0.999 \\
9\end{array}$ & 0.0598 & 0.93 & 0.0699 & 0.981 \\
\hline Xylene & 9.917 & 9.99 & 0.097566 & 1 & 0.0596 & 0.91 & 0.0382 & $\begin{array}{c}0.958 \\
5\end{array}$ \\
\hline
\end{tabular}




\subsection{Effect of adsorbate concentration and adsorption isotherms}

The effects of initial BTEX concentration in the range of $10-40 \mathrm{mg} / \mathrm{l}$ (of each) were evaluated in the initial $\mathrm{pH}$ of the groundwater until equilibrium at $25 \circ \mathrm{C}$ as presented in Fig 8 . Increasing the BTEX concentration increases Van der Waal's forces which drive adsorbates to the active sites of the adsorbent $[9,15]$.Therefore, maximum capacity of the adsorbent was increased by increasing the adsorbate (Fig 8.). However, removal efficiency was decreased by increasing the BTEX cobcentration (Fig 9.).

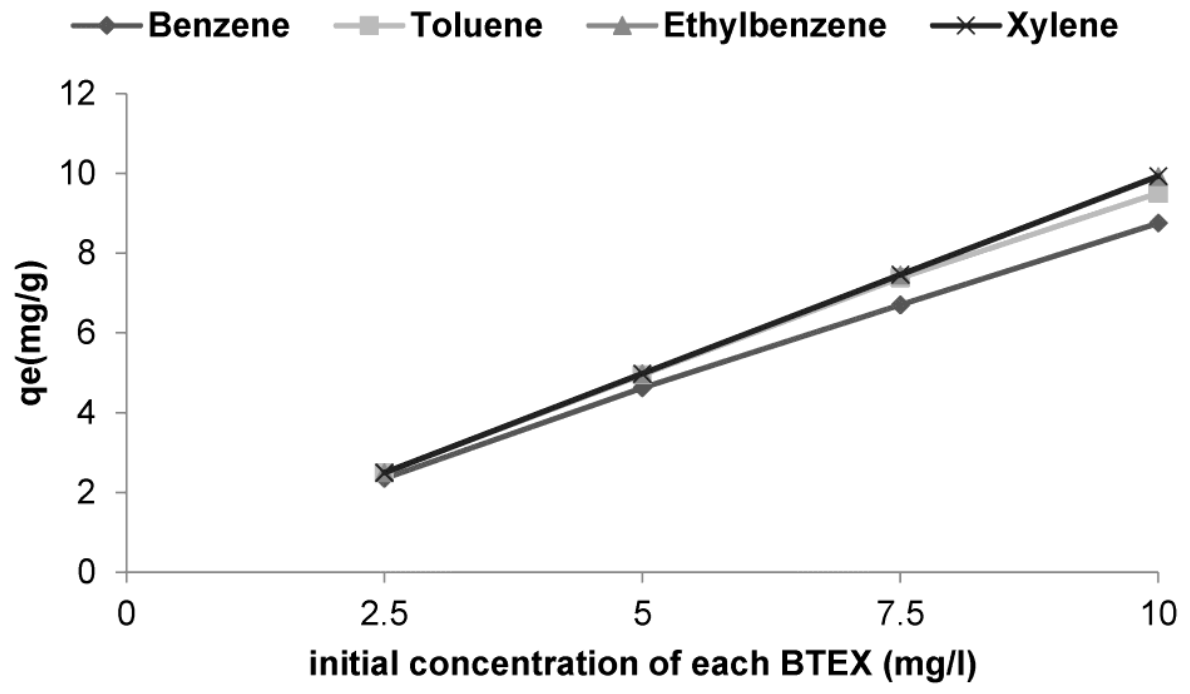

Fig 8. maximum capacity of the adsorbent for BTEX removal at different BTEX concentrations

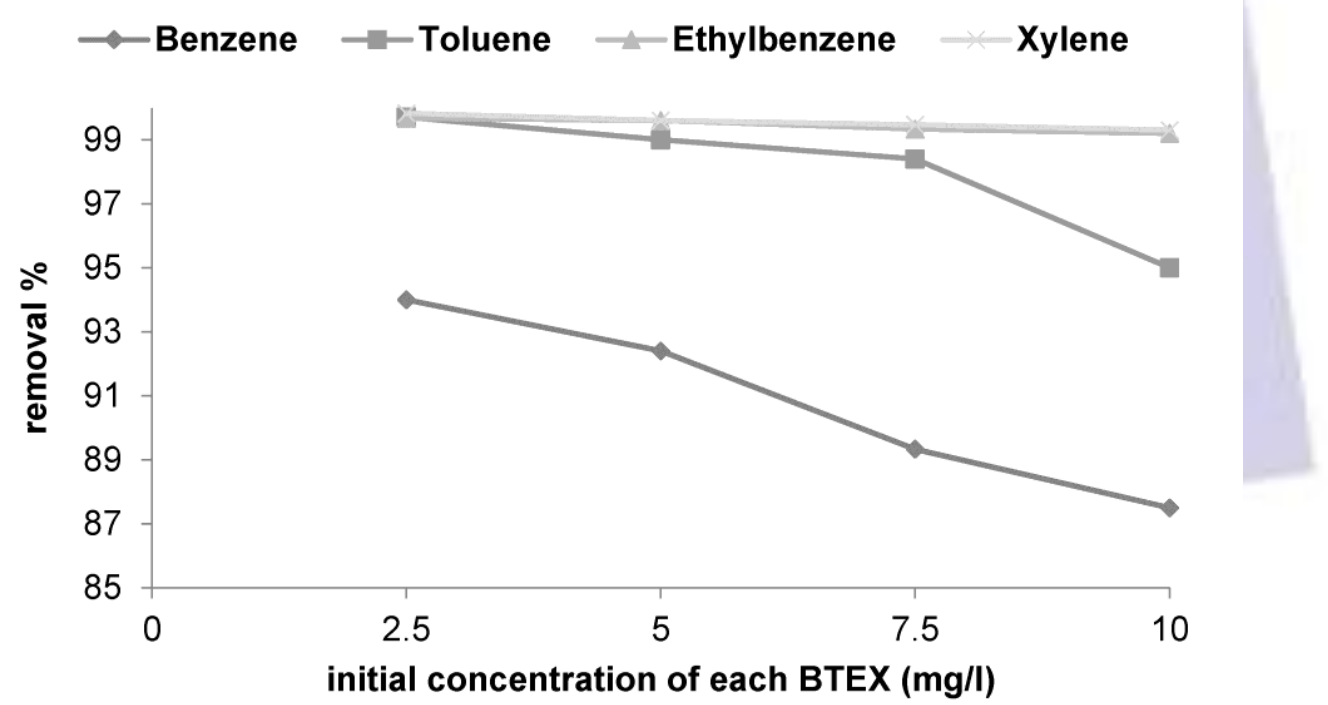

Fig 9. Removal percentage of BTEX at different BTEX concentrations

For these data to be meaningful, various isotherm models such as Freundlich and Langmuir models are employed. These equations have great importance, because they are dealing with different initial concentrations of BTEX and their interpretations are applicable in designing adsorption systems. In general, isotherm equations are the relationship between equilibrium capacity of the adsorbent (qe) and the final concentration of the adsorbate in the solution (Ce) at constant temperature. These models are originally developed for gaseous phase, and later would be proved to be applicable to liquid phase too [24].

Freundlich isotherm Equation 5. is an empirical equation which can explain many organic contaminants' adsorption on adsorbents [25]. 


\begin{tabular}{l|l|}
\hline $\mathrm{q}_{\mathrm{e}}=\mathrm{KC}_{\mathrm{e}}^{1 / \mathrm{n}}$ & Equation 5 \\
or & \\
$\mathrm{Lnq}_{\mathrm{e}}=\mathrm{LnK}+\frac{1}{\mathrm{n}} \mathrm{LnC}$ & \\
\hline
\end{tabular}

Where qe $(\mathrm{mg} / \mathrm{g})$ is the maximum adsorption capacity of the adsorbent, and $\mathrm{Ce}(\mathrm{mg} / \mathrm{l})$ is the concentration of the adsorbate in the solution after equilibrium. $\mathrm{Kf}\left(\mathrm{lkg}^{-1}\right)$ is related to capacity of the adsorbatebinding [24] and $\mathrm{n}$ (dimensionless) is dependent on adsorbent heterogeneity [25] and intensity of adsorption [26]. The Freundlich isotherm model is used for multilayer adsorption on the heterogeneous adsorbent surface [9].

Langmuir isotherm Equation 6.can be derived by theoretical assumptions (Wang, 2006) and describes monolayer adsorption.

$$
\frac{1}{q_{e}}=\frac{1}{q_{\max }}+\left(\frac{1}{q_{\max } K_{L}}\right) \frac{1}{C_{e}}
$$

Equation 6

qe and Ce have the same definitions as in Freundlich equation. qmax $(\mathrm{mg} / \mathrm{g})$ is the maximum capacity of the adsorbent when a monolayer of the adsorbent forms on it [15] and $\mathrm{K}_{\mathrm{L}}$ is the Langmuir constant related to the heat of adsorption.

$\mathrm{K}$ and $\mathrm{n}$ from Freundlich equation are obtained by plotting Inqe against InCe.qmax and $\mathrm{K}_{\mathrm{L}}$ from Langmuir equation are obtained by plotting $1 / \mathrm{qe}$ against $1 / \mathrm{Ce}$. These constants are summarized in Table 6 . According to $\mathrm{R}^{2}$ of them, both equations can explain BTEX adsorption on the adsorbent. This case is similar to adsorption of BTEX on Montmorillonite Organo-Clays. In these cases, some interactions are occurred between formed monolayer and aggregated BTEX species [24].

Table 6. Langmuir, Freundlich and D-R isotherm parameters for the adsorption of BTEX by paper mill sludge-based adsorbent

\begin{tabular}{|c|c|c|c|c|c|c|c|c|c|}
\hline \multirow{2}{*}{$\begin{array}{c}\text { Parameters } \\
\text { Contaminant }\end{array}$} & \multicolumn{3}{|c|}{ Langmuir isotherm } & \multicolumn{3}{c|}{ Freundlich isotherm } & \multicolumn{3}{c|}{$\mathrm{D}-\mathrm{R}$ isotherm } \\
\cline { 2 - 10 } & $\mathrm{K}_{\mathrm{L}}$ & $\mathrm{q}_{\max }$ & $\mathrm{r}^{2}$ & $\mathrm{~K}_{\mathrm{f}}$ & $\mathrm{n}$ & $\mathrm{r}^{2}$ & $\mathrm{q}_{\mathrm{m}}$ & $\mathrm{E}(\mathrm{kJ} / \mathrm{mol})$ & $\mathrm{r}^{2}$ \\
\hline Benzene & 12.77 & 1.5 & 0.97 & 7.79 & 1.63 & 0.95 & 8.76 & 3.02 & 0.973 \\
Toluene & 7.96 & 59.81 & 0.95 & 19.49 & 3.07 & 0.97 & 9.55 & 7.22 & 0.977 \\
Ethylbenzene & 13.93 & 26.59 & 0.99 & 12.94 & 1.7 & 0.98 & 16.8 & 6.02 & 0.994 \\
Xylene & 9.64 & 79.77 & 0.97 & 36.97 & 2 & 0.98 & 14.4 & 6.97 & 0.978 \\
\hline
\end{tabular}

Because $\mathrm{n}$ is higher than 1 in all cases, it is concluded that the adsorbent is heterogeneous and has a broad range of pore sizes and shapes, adsorption site energies, and surface chemical groups which was proved in FTIR analysis [25]. It is also indicative of favorable adsorption and strong bond between BTEX and the adsorbent [26]. It is noteworthy that $n$ and $K$ values obtained here are applicable in initial concentration ranges of this experiment, so they are specific to the experiment. In other cases, they should be adjusted [27].

The $\mathrm{K}$ values for BTEX compounds are in order of $\mathrm{X}>\mathrm{E}>\mathrm{T}>\mathrm{B}$. This can be attributed to larger size of xylene than ethylbenzene than toluene than benzene which leads to higher hydrophobicity.

\begin{tabular}{|l|l|}
\hline $\mathrm{R}_{\mathrm{L}}=\frac{1}{1+\mathrm{K}_{\mathrm{L}} \mathrm{C}_{0}}$ & Equation 7 \\
\hline $\mathrm{R}_{\mathrm{L}>1}$ & Unfavorable adsorption \\
\hline $\mathrm{R}_{\mathrm{L}=1}$ & Linear Adsorption \\
\hline $0<\mathrm{R}_{\mathrm{L}<1}$ & Favorable adsorption \\
\hline
\end{tabular}


One of the important parameters obtained from Langmuir equation is $\mathrm{K}_{\mathrm{Lqmax}}\left(\mathrm{I} . \mathrm{kg}^{-1}\right)$ representing the maximum adsorption buffering capacity. This parameter is indicative of capacity of the adsorbent to keep the adsorbate in itself [24]. Another important parameter derived from Langmuir equation is constant separation factor or equilibrium parameter $\mathrm{RL}$ (dimensionless) Equation 7.which is indicative of favorability and feasibility of the adsorption process [28]. C0 is the initial concentration of the adsorbate. RLvalue in all initial concentrations are in the range of $0-1$ indicating favorable adsorption of BTEX on the adsorbent.

Adsorption data can be explained by Dubinin-Rudushkevich isotherm too (Equation 8). This equation can determine type of the adsorption process as physical or chemical.

\begin{tabular}{|l|l|}
\hline $\ln \mathrm{q}_{\mathrm{e}}=\ln \mathrm{q}_{\mathrm{m}}-\beta \varepsilon^{2}$ & Equation 8 \\
\hline
\end{tabular}

In this equation, $q m(\mathrm{mg} / \mathrm{g})$ is theoretical saturation sorption capacity, $\beta(\mathrm{kJ} / \mathrm{mol})$ is related to mean adsorption energy, and $\varepsilon$ (Polany Potential) is equal to RT. $\ln (1+1 / \mathrm{Ce}) . \mathrm{R}(8.314 \mathrm{~kJ} / \mathrm{mol} . \mathrm{K})$ is gas constant, and $\mathrm{T}(\mathrm{K})$ is temperature. Intercept and slope of Inqe versus $\varepsilon^{2}$ are Inqm and $\beta$ respectively. The most important parameter of Dubinin-Rudushkevick equation is $\mathrm{E}(\mathrm{kJ} / \mathrm{mol})$ or mean adsorption energy Equation 9.

\begin{tabular}{|l|l|}
\hline $\mathrm{E}=\frac{1}{\sqrt{2 \beta}}$ & Equation 9 \\
\hline
\end{tabular}

The type of adsorption process can be determined by value of $E$. According to Table 5 the $E$ values of BTEX adsorption on paper mill sludge-based adsorbent are in range of $3.02-6.97 \mathrm{~kJ} / \mathrm{mol}$. Therefore, BTEX is physically adsorbed on this adsorbent.

Table 5. Type of adsorption process according to $E$ value

\begin{tabular}{|c|c|}
\hline Type Of Adsorption & E Value \\
\hline Chemical Ion Exchange & $8-16 \mathrm{~kJ} / \mathrm{mol}$ \\
\hline Physical Adsorotion & $<8 \mathrm{~kJ} / \mathrm{mol}$ \\
\hline Chemical Adsorption & $>16 \mathrm{~kJ} / \mathrm{mol}$ \\
\hline
\end{tabular}

\subsection{Effect of Adsorbent Concentration}

Fig. 10 and Fig. 11 show the effect of adsorbent dosage on maximum capacity of adsorbent and adsorption percentage respectively. The removal percentage of BTEX went up with the increase in adsorbent dosage, because, more adsorbent in the solution provided more adsorption sites for adsorbate molecules. In the adsorption experiments, along with increase of adsorbent dosage from $250 \mathrm{mg} / \mathrm{l}$ to $1500 \mathrm{mg} / \mathrm{l}$, the percentage of BTEX adsorbed increased from $85 \%$ to $98 \%$, approximately. To remove $98 \%$ of benzene, one more experiment was conducted by $2000 \mathrm{mg} / \mathrm{l}$ adsorbent. As indicated in Error! Reference source not found., by increasing the adsorbent dosage, the amount of BTEX adsorbed per unit mass of the adsorbent (qe) decreased.

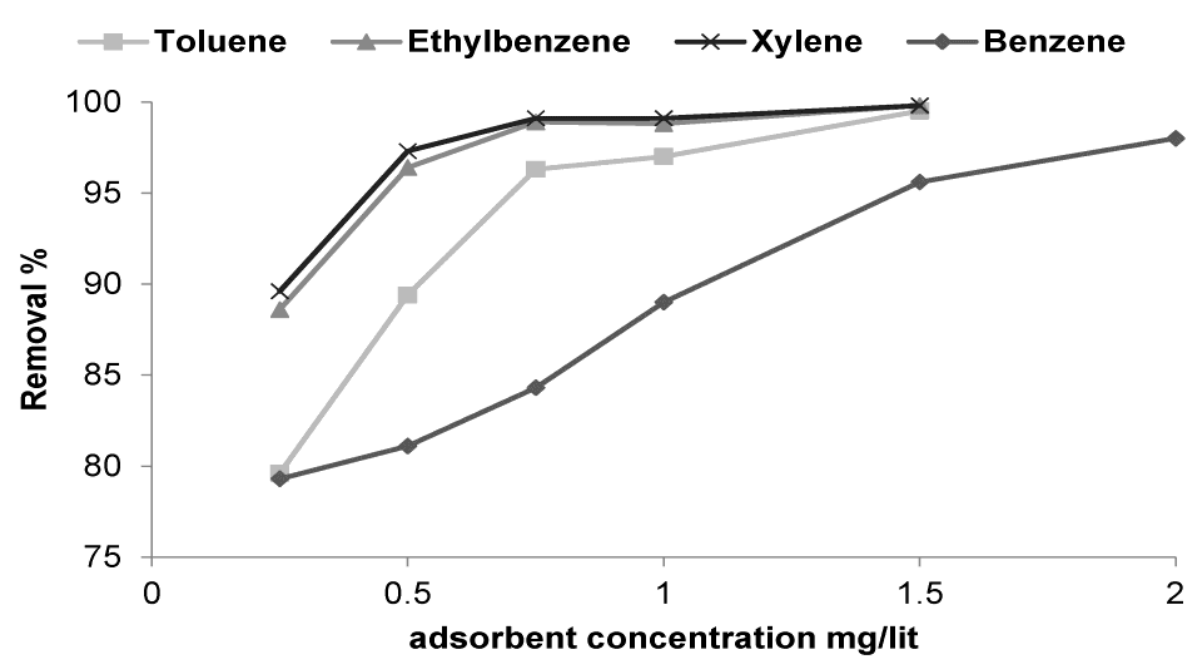

Fig 10. removal of BTEX at different dosages of the adsorbent 


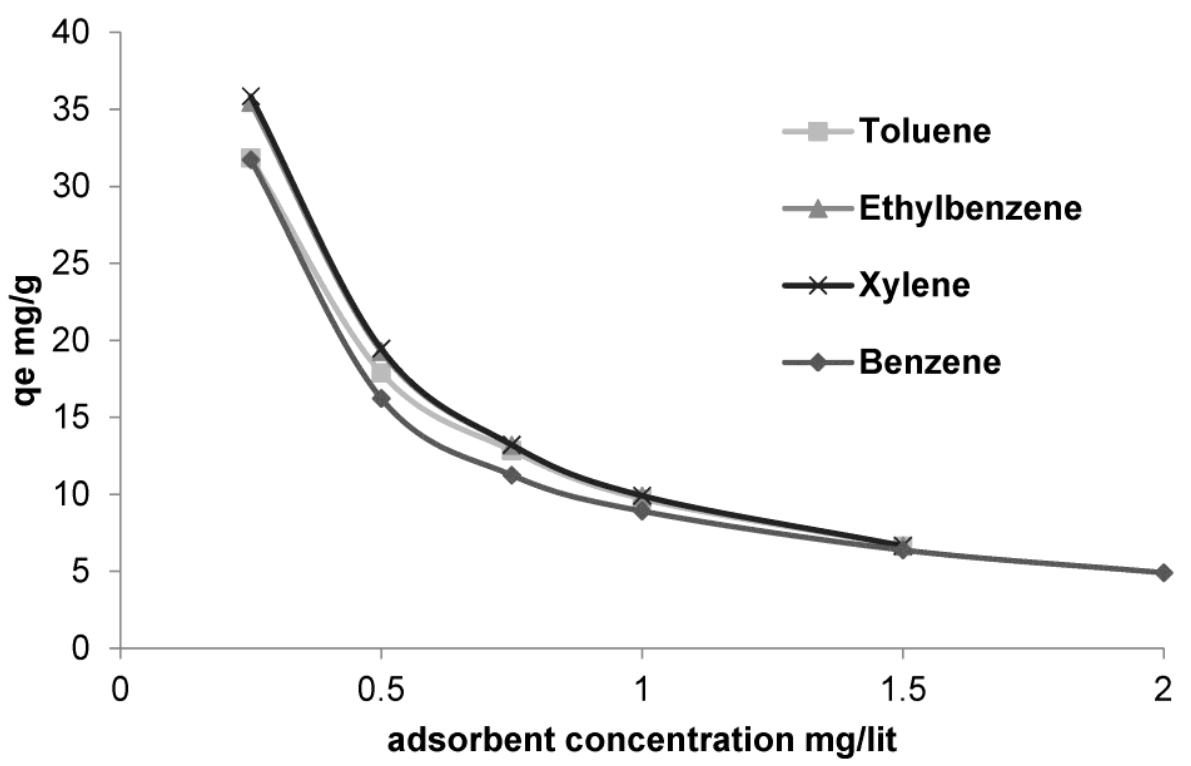

Fig 11. maximum capacity of adsorbent (qe) for removing BTEX at different adsorbent dosages

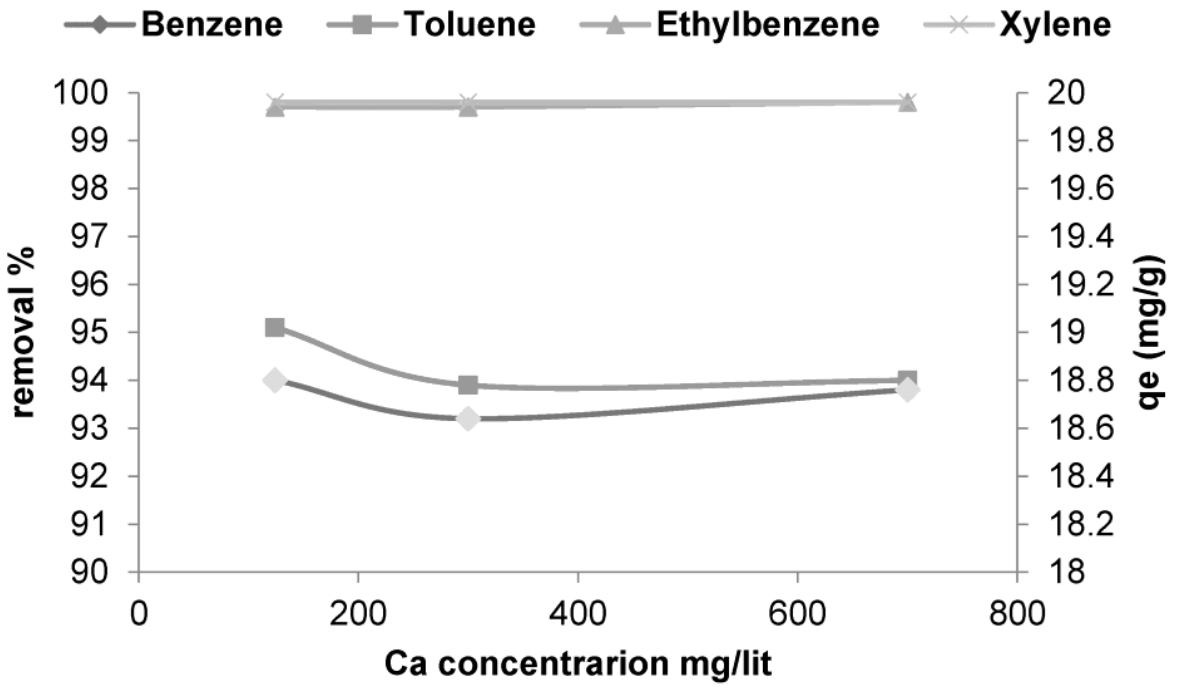

Fig 12. removal of $\mathrm{BTEX}$ at different $\mathrm{Ca}^{2+}$ concentrations

\subsection{Effect of ionic strength}

Fig. 12 exhibits the effect of solution ionic strength on the BTEX adsorption via the adsorbent at $40 \mathrm{mg} / \mathrm{l}$ of BTEX and $500 \mathrm{mg} / \mathrm{l}$ of the adsorbent. The ionic strength $(\mathrm{Y})$, which is a general property of the solution affecting the affinity between the solute and the aqueous phase, was adjusted using $\mathrm{CaCl}_{2}$. As seen, the change iny shows insignificant impacts on BTEX adsorption, reflecting high stability of the adsorbent in a wide range of solution ionic strength. Nourmoradi et al. showed insignificant effect of $\mathrm{Ca}^{2+}$ concentration $(20-100 \mathrm{mg} / \mathrm{l})$ on BTEX adsorption on montmorillonite modified with nonionic surfactant [9]. Su et al. [29] showed insignificant effect of $\mathrm{NaCl}$ concentration (0.02-0.2 $\mathrm{M})$ on $\mathrm{BTEX}$ adsorption on $\mathrm{NaOCl}$-oxidized carbon nanotubes.

\subsection{BTEX adsorption from groundwater contaminated by gasoline}

Since the major source of BTEX contamination in water is gasoline, and gasoline is very complex compound, it is important to evaluate capability of a removal method in real conditions. Table 7 shows the amount of BTEX in used gasoline. 
Table 7. BTEX concentration in gasoline

\begin{tabular}{|c|c|c|c|c|}
\hline \multirow{2}{*}{ Fraction } & \multicolumn{4}{|c|}{ BTEX percentage } \\
\cline { 2 - 5 } & benzene & toluene & ethylbenzene & xylene \\
\hline Mass Fraction out of whole BTEX & $11.2 \%$ & $19.2 \%$ & $11.4 \%$ & $58.1 \%$ \\
\hline Mass Fraction out of whole gasoline & $2.2 \%$ & $3.77 \%$ & $2.85 \%$ & $11.39 \%$ \\
\hline
\end{tabular}

According to Fig. 13 higher initial concentrations reduced removal percentage. Since the amounts of the four target compounds (benzene, toluene, ethylbenzene and xylene) are not equal to each other, exact comparison of BTEX removal capability using gasoline and pure BTEX, is impossible. However, approximate comparison was conducted by putting results of same compounds in a diagram, as shown in Fig. 14 it is not surprising that BTEX removal percentage from gasoline spiked water is lower than removal percentage from pure BTEX spiked water .In addition, this reduction can be attributed to the existence of several impurities in the gasoline which compete with BTEX compounds in reaching to the adsorotion sites.

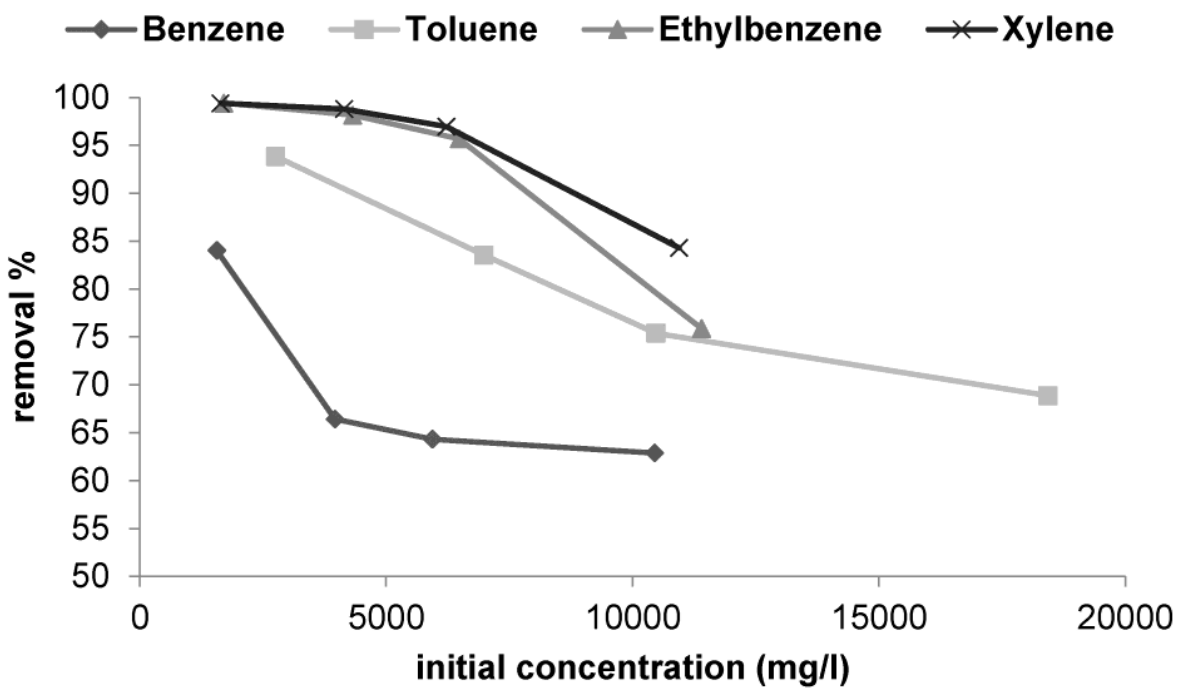

Fig 13. removal of BTEX from groundwater contaminated with gasoline. Concentration of the adsorbent is 1000 $\mathrm{mg} / \mathrm{l}$.
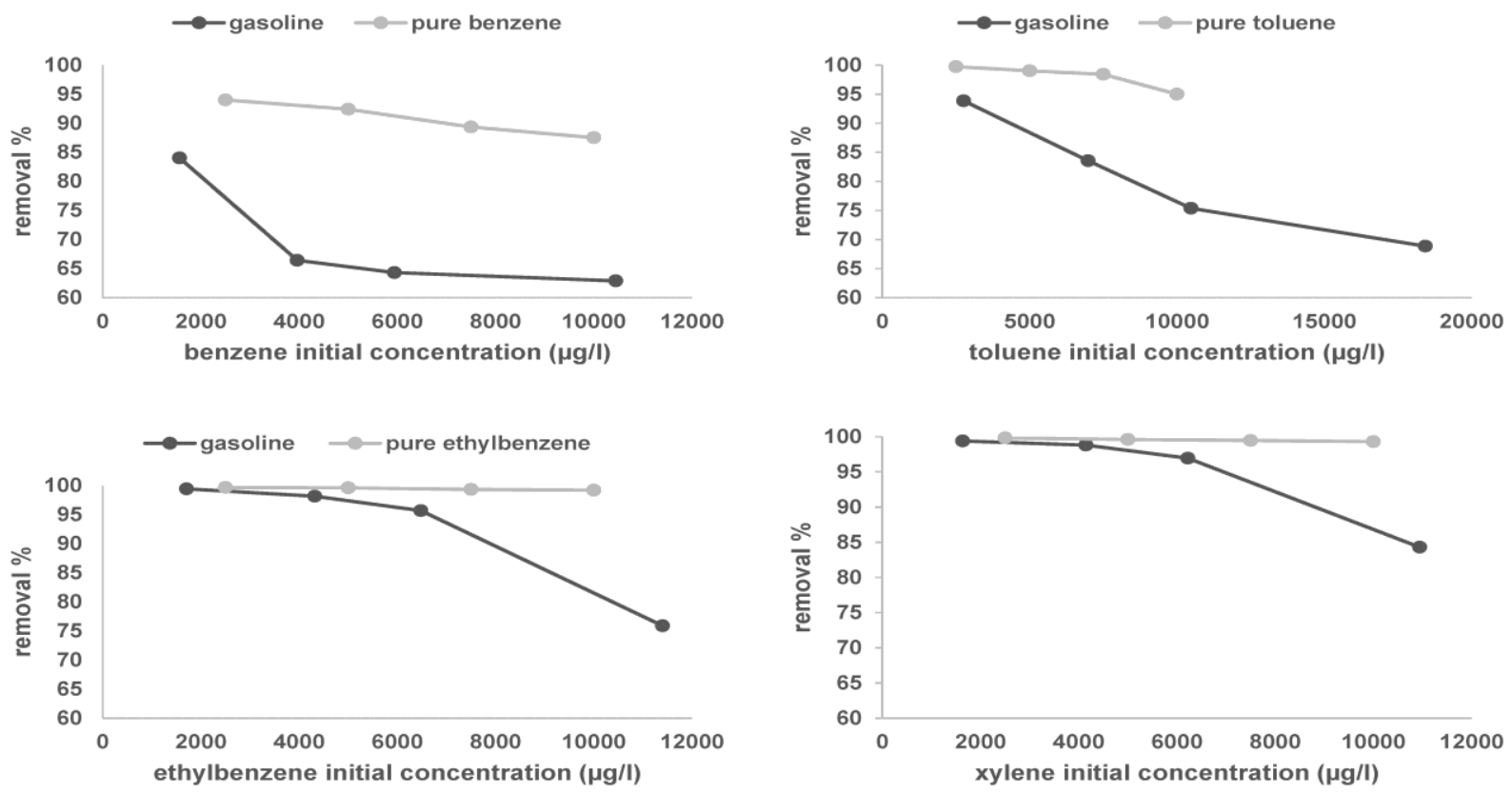

14. Comparison of BTEX removal from groundawater contaminated by pure BTEX and gasoline 
Unfortunately, there are very few experiments in which BTEX removal from gasoline spiked water was investigated. Table 8 compares results of conducting some methods for removal of BTEX from gasoline spiked groundwater. It indicates that adsorption method is more capable than advanced oxidation processes (AOPs) in removal of BTEX. It is due to high sensibility of these methods to existence of different compounds and especially certain ions such as carbonate and bicarbonate which are $\mathrm{HO} \cdot$ scavenger. Another drawback of AOPs are formations of toxic intermediates which are sometimes more dangerous than initial contaminants. However, in the case of appropriate monitoring and operation, they are capable of mineralizing many persistent pollutants.

Table 8. Comparison of advanced oxidation processes (AOPs) and adsorption for removal of BTEX from groundwater samples contaminated by gasoline. Initial concentrations ( $\mathrm{mg} / \mathrm{l})$ for all of AOPs are equal.

\begin{tabular}{|c|c|c|c|c|c|c|c|c|c|c|c|}
\hline & \multicolumn{7}{|c|}{ Alizadeh Fard et al. 2013} & \multicolumn{4}{|c|}{ Current study } \\
\hline & \multirow{3}{*}{$\mathrm{C}_{0}$} & \multicolumn{6}{|c|}{ Removal Efficiency(\%) } & \multirow{3}{*}{$\mathrm{C}_{0}$} & \multirow{3}{*}{ 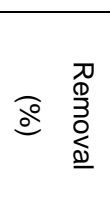 } & \multirow{3}{*}{$\mathrm{C}_{0}$} & \multirow{3}{*}{ ๙ิ } \\
\hline & & \multirow{2}{*}{ Fenton } & \multirow{2}{*}{$\begin{array}{l}\text { Photo- } \\
\text { Fenton }\end{array}$} & \multicolumn{2}{|c|}{ Natural Light } & \multicolumn{2}{|c|}{ Artificial Light } & & & & \\
\hline & & & & $\mathrm{UV} / \mathrm{TiO}_{2}$ & $\mathrm{UV} / \mathrm{TiO}_{2} / \mathrm{H}_{2} \mathrm{O}_{2}$ & $\mathrm{UV} / \mathrm{TiO}_{2}$ & $\mathrm{UV} / \mathrm{TiO}_{2} / \mathrm{H}_{2} \mathrm{O}_{2}$ & & & & \\
\hline$B$ & 0.508 & & 84.25 & 61.22 & 75.20 & 80.12 & 91.34 & 1.6 & 84.02 & 10.5 & 62.87 \\
\hline $\mathrm{T}$ & 0.778 & & 89.2 & 77.51 & 86.63 & 82.39 & 92.93 & 2.8 & 93.84 & 18.4 & 68.86 \\
\hline EB & 0.934 & & 89.5 & 86.72 & 89.72 & 83.51 & 95.40 & 1.7 & 99.41 & 11.4 & 75.88 \\
\hline $\mathrm{X}$ & 0.631 & & 79.9 & 58.95 & 70.68 & 71.63 & 88.11 & 1.6 & 99.39 & 10.9 & 84.28 \\
\hline
\end{tabular}

\subsection{Comparative studies}

Table 9.shows comparison of capability of some adsorbents prepared from waste materials to remove BTEX from aqueous solutions. Selection of paper presented by Daifullah for comparison purpose is due to similarity of initial conditions of it to this study (each BTEX: $10 \mathrm{mg} / \mathrm{l}$, adsorbent: $1 \mathrm{~g} / \mathrm{l})$. The paper mill sludge-based adsorbent has better performance than other adsorbents, despite its slightly less surface area and pore volume. This issue proves that presence of surface functional groups especially carboxylic group is the main reason for the BTEX adsorption [22].

Table 9. Comparison of maximum capacity (qe $\mathrm{mg} / \mathrm{g}$ ) of different adsorbents prepared from different waste materials for adsorption of BTEX.

\begin{tabular}{|c|c|c|c|c|c|c|c|c|}
\hline Adsorbent precursor & $\begin{array}{l}\mathrm{S}_{\mathrm{BET}} \\
\mathrm{m}^{2} / \mathrm{g}\end{array}$ & $\begin{array}{c}\mathrm{V} \\
\mathrm{m}^{3} / \mathrm{g}\end{array}$ & $\begin{array}{l}D \\
A^{0}\end{array}$ & B & $\mathrm{T}$ & EB & $x$ & Reference \\
\hline Date pits & 771 & 0.537 & 27.8 & 8.8 & 5 & 5.6 & 6.2 & \multirow{6}{*}{ 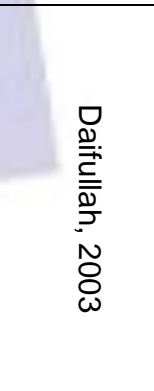 } \\
\hline Cotton stalks & 1183 & 1.055 & 35.8 & 3 & 6.7 & 8.7 & 9.3 & \\
\hline Peach stones & 1346 & 0.935 & 27.8 & 3 & 6.5 & 8.3 & 8.7 & \\
\hline Almond shells & 1279 & 1.011 & 31.2 & 1.3 & 5 & 6.5 & 7.4 & \\
\hline Olive stones & 848 & 0.632 & 29.8 & 8.3 & 5.8 & 6.6 & 7.2 & \\
\hline $\begin{array}{l}\text { Powdered activated carbon } \\
\text { (Prolabo) }\end{array}$ & - & - & - & 7.95 & 9.2 & 9.25 & 9.92 & \\
\hline Paper mill-based & 613 & 0.642 & 83.76 & 9.22 & 9.96 & 9.96 & 9.99 & this study \\
\hline
\end{tabular}

\section{Conclusion}

An adsorbent was prepared through chemical activation and pyrolysis of dried and sieved paper mill sludge. Its surface chemical functional groups leading to high capability in removal of BTEX from contaminated groundwater in a variety of $\mathrm{pHs}$, initial concentrations of BTEX and ionic strengths, which were more than $99 \%$ within two hours in many cases. However, removal efficiency of benzene was lower and slower than others due to its low hydrophobicity. The most superiority of the adsorbent has revealed after appropriate removal of BTEX from groundwater gasoline contaminated samples, especially in comparison with other methods like AOPs. 


\section{ACKNOWLEDGMENTS}

The authors wish to acknowledge the Department of Environmental Engineering, Graduate Faculty of Environment, University of Tehran.

\section{REFERENCES}

[1] Nollet, L. M. L., (2006) Chromatographic Analysis of the Environment (Third Edition), Taylor \& Francis Group, LLC

[2] Aivalioti, M., Papoulias, P., Kousaiti, A., Gidarakos, E. (2012) Adsorption of BTEX, MTBE and TAME on natural and modified diatomite, Journal of Hazardous Materials Volumes 207-208, 117-127

[3] Wilbur, S. and Bosch, S. (2004) Interaction Profile for: Benzene, Toluene, Ethylbenzene, and Xylenes (BTEX), Agency for Toxic Substances and Disease Registry, US Department of Health and Human Services Public Health Service, Atlanta, GA, 2004.

[4] World Health Organization, (2008) Guidelines for Drinking-water Quality (3rd ed.), Vol. 1, World Health Organization, Geneva, 2008.

[5] Yang, R. T. (2003) Adsorbents: fundamentals and applications, John Wiley \& Sons, Inc.

[6] Wang, L. K., Hung, Y. T., Shammas, N. K. (editors), (2006) Advanced Phisycochemical Treatment Processes, Humana Press, Chapter 4.

[7] Bansal, R. C. and Goyal, M. (2005) Activated Carbon Adsorption, CRC Press Taylor \& Francis Group

[8] Ren, X., Chen, C., Nagatsu, M., Wang, X. (2011) Carbon nanotubes as adsorbents in environmental pollution management: A review, Chemical Engineering Journal 170 395-410

[9] Nourmoradi, H., Nikaeena, M., Khiadani, M. (2012) Removal of benzene, toluene, ethylbenzene and xylene (BTEX) from aqueous solutions by montmorillonite modified with nonionic surfactant: Equilibrium, kinetic and thermodynamic study, Chemical Engineering Journal $191341-348$

[10] Torabian, A., Kazemian, H., Seifi, L., NabiBidhendi, H., Azimi, A. A., Ghadiri, S. K. (2010) Removal of Petroleum Aromatic Hydrocarbons by Surfactant-modified Natural Zeolite: The Effect of Surfactant, Clean 38(1), 77-83

[11] Demirbas, A. (2009) Agricultural based activated carbons for the removal of dyes from aqueous solutions: A review, Journal of Hazardous Materials 167 1-9

[12] Ahmaruzzaman, M. (2011) Industrial wastes as low-cost potential adsorbents for the treatment of wastewater laden with heavy metals, Advances in Colloid and Interface Science 166 36-59

[13] Smith, K.M., Fowler, G.D., Pullket, S., Graham, N.J.D. (2009) Sewage sludge-based adsorbents: A review of their production, properties and use in water treatment applications, water $r$ ese arch 43 2569-2594

[14] Calace, N., Nardi, E., Petronio, B. M., Pietroletti, M. (2002) Adsorption of phenols by papermillsludges, Environmental Pollution 118 315-319

[15] Li, W., Yue, Q., Tu, P., Ma, Z., Gao, B., Li, J., Xu, X. (2011) Adsorption characteristics of dyes in columns of activated carbon prepared from paper mill sewage sludge, Chemical Engineering Journal 178 197-203

[16] Bhatnagar, A., Sillanpää, M., (2010) Utilization of agro-industrial and municipal waste materials as potential adsorbents for water treatment-A review, Chemical Engineering Journal 157 277-296

[17] USEPA, Method 8260B Volatile Organic Compounds by Gas Chromatography/Mass Spectrometry (GC/MS),US Environmental Protection Agency, Washington DC, 1996.

[18] USEPA, Method 5035 Closed-system Purge-and-trap and Extraction for Volatile Organics in Soil and Waste Samples, US Environmental Protection Agency, Washington DC, 1996.

[19] Khalili, N. R., Campbell, M., Sandi, G., Golas, J. (2000) Production of micro- and mesoporous activated carbon from paper mill sludge I. Effect of zinc chloride activation, Carbon 38 1905-1915

[20] YU, F., Ma, J., Wu, Y. (2011) Adsorption of toluene, ethylbenzene and xylene isomers on multi-walled carbon nanotubes oxidized by different concentration of $\mathrm{NaOCl}$, Front. Environ. Sci. Engin. China 6:3 320-329

[21] Ros, A., Lillo-Ro'denas, M.A., Fuente, E., Montes-Mora'n, M.A., Martı'n, M.J., Linares-Solano, A. (2006) High surface area materials prepared from sewage sludge-based precursors, Chemosphere 65 132-140

[22] Daifullah, A.A.M., Girgis, B.S., (2003) Impact of surface characteristics of activated carbon on adsorption of BTEX, Colloids and Surfaces A: Physicochem. Eng. Aspects 214 181/193

[23] Calace, N., Nardi, E., Petronio, E. M., Pietroletti, M., Tosti, G. (2003) Metal ion removal from water by sorption on paper mill sludge, Chemosphere 51 797-803 
[24] Sharmasarkar, S., Jaynes, W. F., Vance, G. F. (2000) BTEX sorption by montmorilloniteorgano-clays: TMPA, ADAM, HDTMA, Water, Air, and Soil Pollution119 257-273

[25] Edwaldz, J. K. (editor), (2011) Water Quality and Treatment, A Handbook on Drinking Water (6th edition), American Water Works Association, The McGraw-Hill Companies, Chapter 14.

[26] Koyuncu, H., Yildiz, N., Salgin, N., Körǒglu, F., Calimli, L. (2011) Adsorption of o-, m- and p-nitrophenols onto organically modified bentonites, Journal of Hazardous Materials 185 1332-1339

[27] Wang, D., McLaughlin, E., Pfeffer, R., Lin, Y. S. (2011) Adsorption of Organic Compounds in Vapor, Liquid, and Aqueous Solution Phases on Hydrophobic Aerogels, Ind. Eng. Chem. Res., 50:21, 12177-12185

[28] Khenifi, A. Bouberka, Z., Sekrane, F., Kameche, M., Derriche, Z. (2007) Adsorption study of an industrial dye by an organic clay, Adsorption, 2007 (13) 149-158

[29] Su, F., Lu, C., Hu, S. (2010) Adsorption of benzene, toluene, ethylbenzeneandp-xylene by NaOCl-oxidized carbon nanotubes, Colloids and Surfaces A: Physicochem. Eng. Aspects 353 83-91 